\title{
Grænsen i mindretals- og Schengen-perspektiv
}

\author{
af LARS N. HENNINGSEN
}

Den 25. marts 2001 var en skelsættende dag. Den såkaldte Schengen-aftale trådte i kraft og medførte, at landegrænsen kunne passeres uden at vise pas. Helt anderledes havde det været i de første år efter 1945, hvor grænsen var næsten hermetisk lukket. Grænsebefolkningens og især mindretallenes hedeste ønsker fra den lukkede grænses år om frit samkvem hen over grænsen var blevet virkelighed mere end nogensinde før. Arkivar Lars N. Henningsen, Aabenraa, sætter her den nye virkelighed i perspektiv og tegner en skitse af grænsens betydning for befolkningen gennem 80 år.

\section{Indledning}

Søndag den 1. august 1920 kørte lærer Christian Johannsen ud af Flensborg nordpå for at besøge familien i Tinglev. Det havde han gjort så ofte, men denne gang formede rejsen frem og tilbage sig lidt anderledes end tidligere. I sin dagbog skrev læreren (på tysk): „Ved Kruså $4 \mathrm{~km}$ nord for Flensborg er grænsen. Man kommer kun igennem med pas. Fra Tinglev medbringer jeg sukker, som dér fås rigeligt og billigere end her. Men man må smugle det igennem ". ${ }^{1}$

Læreren havde god grund til at nævne grænsen. Den var helt ny og føltes endnu lidt uvant. Den 5. maj var de danske grænsegendarmer rykket fra Kongeågrænsen ned til den linje, som havde skilt $1 . \mathrm{og}$ 2. zone ved afstemningerne i februar og marts. Her var der foretaget afspærring til det som nu skulle være grænsen. Den 15 . juni var grænselinjen blevet fastlagt, og den 5 . juli var Nordslesvig formelt blevet overdraget til Danmark. For den almindelige befolkning var det måske mest mærkbare, at der natten mellem 26. og 27. maj var indført pastvang mellem de tidligere afstemningszoner. Det var en skelsættende begivenhed, der på det praktiske plan markerede den endelige deling af Sonderjylland. ${ }^{2}$

Netop denne grænse blev i de følgende år af afgørende betydning for landsdelen. Lige fra afstemningstiden og frem til 1950'erne blev 


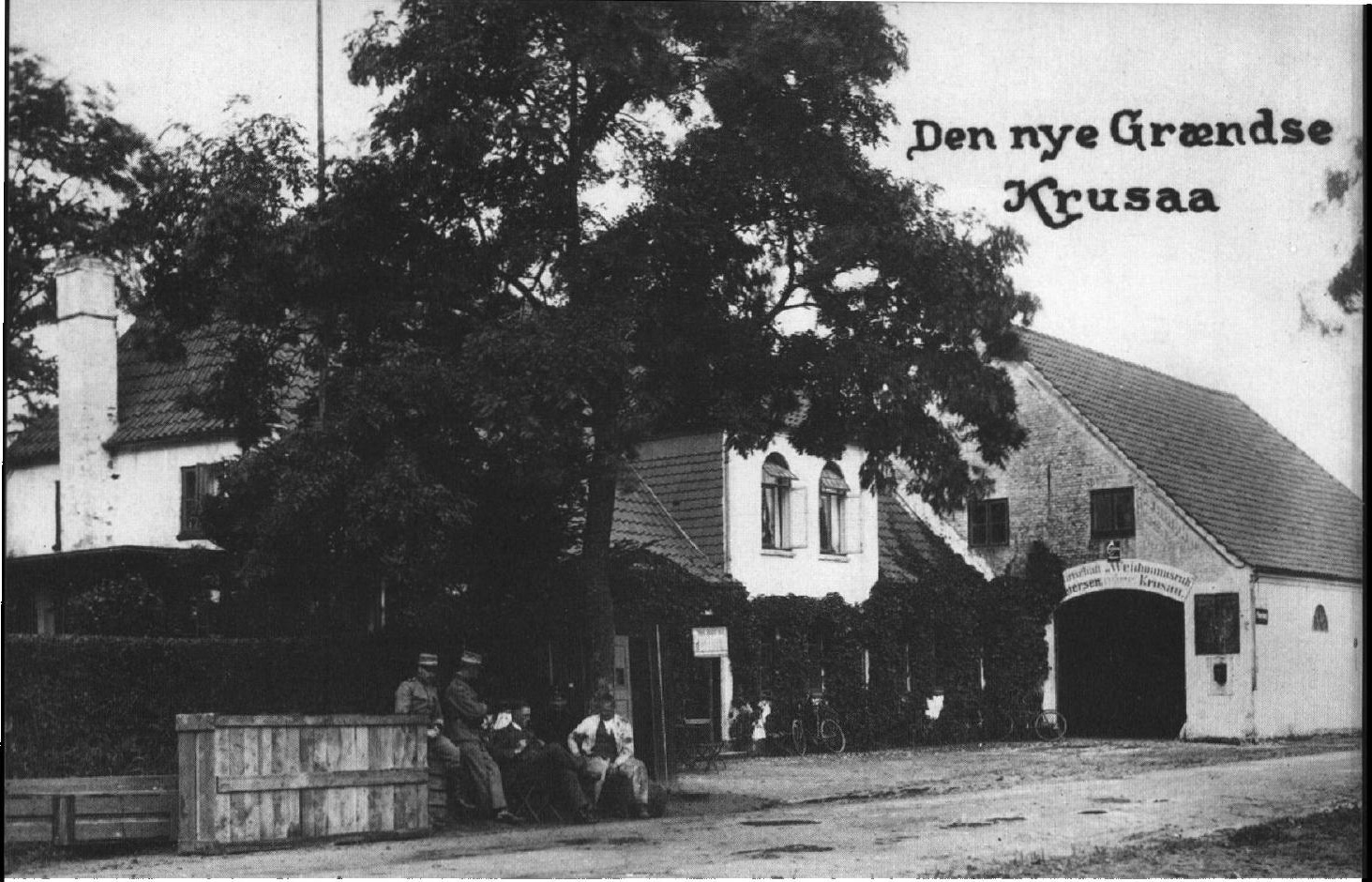

Den nye grænse $i 1920$ betød blandt meget andet, at der skulle vises pas. I den forste tid var pas- og toldkontrollørernes faciliteter dog kun begrænsede. Her fotos af

1920-grænsen selve nogleproblemet $i$ grænselandshistorien. På det statspolitiske plan blev grænsen og spørgsmålet om dens anerkendelse omdrejningspunktet $\mathrm{i}$ forholdet mellem Danmark og Tyskland. For den almindelige befolkning, i dagligdagen, dannede grænsen et skel, som skar ind igennem familieforbindelser og erhvervsøkonomiske sammenhænge.

Derfor så lovgiverne det $\mathrm{i}$ de første år efter 1920 som en opgave at prøve at sikre en så let passage af grænsen som muligt. Faktisk blev der opnået gode resultater $\mathrm{i}$ den retning $\mathrm{i}$ årene frem til 1933. Under Hitler-styret og $\mathrm{i}$ krigens år gik udviklingen igen $\mathrm{i}$ retning af en mere lukket grænse. Det afgørende tilbageslag kom dog ført efter 1945. I denne efterkrigstid blev det nødvendigt at gennemføre en næsten hermetisk lukning af grænsen. Det blev mærkbart for befolkningen og allermest måske for de to mindretal. Netop fordi det danske mindretal i syd i disse år gennemgik en så markant udvikling, blev den forstærkede grænsespærring et alvorligt problem i disse år.

Mange kilder fortæller om grænsen som en næsten uoverstigelig mur i de første år efter 1945. „Grænsepærringen forekommer én forfærdelig ubarmhjertig ... Aldrig har jeg troet, at en spærret grænse ville virke sådan på mig. Man kan næsten blive desperat ved den 


\section{Den nye Grændse}

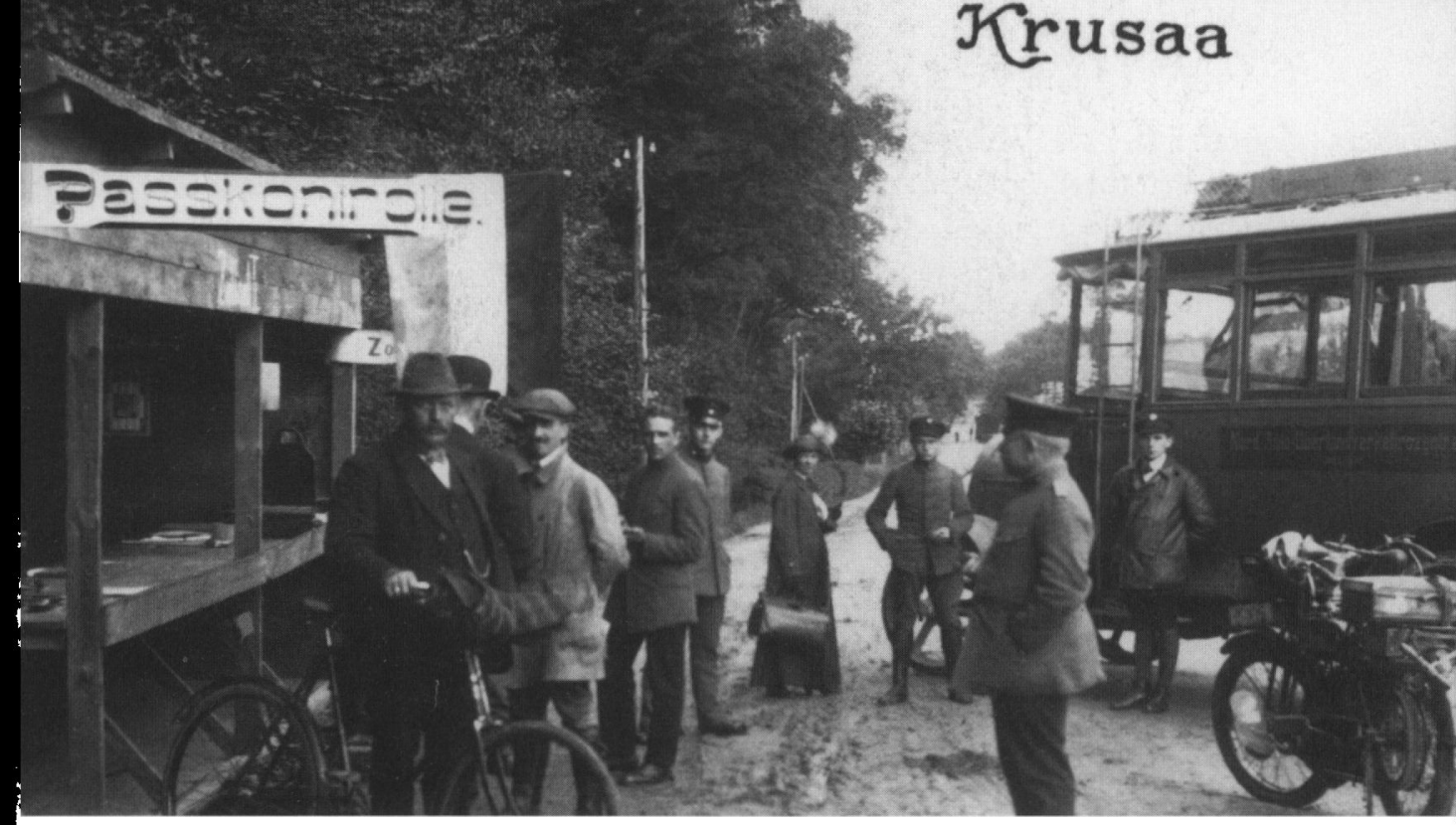

grænseovergangen ved Kruså 1920 i Dansk Centralbibliotek for Sydslesvig (t.v.) og Institut for sonderjysk Lokalhistorie (t.h.).

tanke ikke at kunne komme over, når det passer mig. « Sådan skrev den danske lærerinde Anna Holmgaard i sin dagbog fra Tønning i Sydslesvig den 21. august 1946. Hendes chef, skoleleder Anders Kølvraa, havde netop været i Sønderborg. Selv kunne hun ikke passere grænsen. "Det skar næsten i mig at høre det, jeg ville give meget, både mark og kroner og en del af min ration, for at kunne tage med. ${ }^{3}$

Grænsen var et omstridt tema i denne efterkrigssommer, på udenrigspolitisk plan og i dagligdagen. "Vi havde kørt i et Stræk fra København til Kruså i Glideflugt hen over de brede Bilveje mellem bugnende Kornmarker og grønne Enge. I Sol og Sommerbyger havde vi taget Danmarks Land i Besiddelse: Sjælland-Fyn-Nordslesvig. Og nu lå Flensborg foran os. Men her - nogle få Kilometer uden for Byen blev Landevejen brutalt skåret over.

Er der noget mere selvmodsigende end en Bom tværs over en Landevej? Og så er der endda to Bomme: en, der spærrede Udkørsel fra Danmark, og en der lukkede for Indkørsel til "Germany «. Det lukkede Land - ja lukket mod Nord ...", sådan fortæller dr.phil. Lis Jacobsen om sine indtryk fra en rejse til Sydslesvig i sommeren $1946 .{ }^{4}$ Med lidenskab beretter hun, hvordan grænsespærringen forhindrede sydslesvigerne $i$ at komme til Danmark og forhindrede danske $i$ at besøge 
frænderne i det »forjættede land « Sydslesvig. Den lukkede grænse mod nord forekom mange som en bom for det opblomstrende danske arbejde. Der var brug for lettelser, som kunne muliggøre den kulturelle forbindelse nordpå hen over grænsen.

Endnu værre var det måske for det tyske mindretal i Nordslesvig. Ved det tyske sammenbrud i maj 1945 blev mindretallets forbindelse sydpå totalt spærret. Besøg sydfra blev umulige en tid lang, og f.eks. personer sydfra, som havde været på besøg i Nordslesvig ved kapitulationen, måtte vente til januar 1947, før det atter blev muligt at slippe hjem. Først langsomt normaliseredes forholdene.

Der er således mange grunde til, at efterkrigstiden $\mathbf{i}$ overleveringen kom til at stå som den lukkede grænses år.

I dag, mere end 50 år efter, er verden blevet en anden. Den 25. marts 2001 tiltrådte Danmark Schengen-aftalen. Siden da kan man køre hen over landegrænsen uden at blive kontrolleret, og man skal ikke nødvendigvis vise nogen form for papirer. I dag omdefineres grænsen fra det skillende til det samlende. Der holdes grænsefester og arrangeres grænsesamvær, og grænseoverskridende samarbejde nyder den allerstørste opbakning lokalt og centralt.

En sådan tilstand ville have fået folk i 1946 til at føle sig hensat til et drømmeland.

Der kan derfor være grund til at kaste blikket tilbage for at se, hvordan spørgsmålet om grænsepassage har ændret karakter gennem tiden.

\section{Grænselettelser i mellemkrigsårene}

Grænsen af 1920 lagde en skillelinje gennem et område, som hidtil havde udgjort en økonomisk og handelsmæssig enhed. Gamle erhvervsmæssige relationer og familiebånd blev revet over. Derfor søgte dansk-tyske overenskomster i de følgende år at lette grænsetrafikken mest muligt. Ved overenskomst af 23. oktober 1920 blev der indført specielle grænsepas. De gjaldt kun for rejser inden for grænseområdet, på dansk side amterne Tønder, Aabenraa og Sønderborg, på tysk side Sydtønder og Flensborg landkredse og Flensborg by og blev indført især for at muliggøre grænsebefolkningens rejser til familiebesøg og udøvelse af deres erhverv. Passet skulle yderligere være forsynet med visum, som blev udstedt for 6 måneder. Til indehavere af jorder på begge sider af grænsen kunne udstedes grænsekort, som 
gjorde det muligt at passere grænsen også udenfor de offentlig tilladte overgangssteder. ${ }^{5}$ For ordinære nationalpas blev visumtvangen ophævet for tyske og danske statsborgere i 1926, og samtidig kom der regler om fællespas. De fik især betydning for de to mindretals gruppe- og foreningsrejser ved besøg hos folkefællerne på den anden side af grænsen. ${ }^{6}$

I 1929 indførtes desuden det såkaldte udflugtskort/Ausflugsschein, i folkemunde kaldet »ti-ørespas«, "Groschen-Pass« eller »3-dages pas«. Udflugtskortet blev indført for at stimulere turisttrafikken mellem Danmark og Tyskland og lette samkvemmet mellem beboerne i distrikter på begge sider af grænsen. Formedelst 10 øre på den danske og 10 Pfenning på den tyske side kunne passet frit købes på postkontorer, hos sognefogeder og især ved grænseovergangsstederne. Passet gav ret til én grænsepassage $i$ hver retning og til at opholde sig i indtil tre dage i det nære grænseområde, d.v.s. på dansk side Tønder, Aabenraa og Sønderborg amter, på tysk side landkredsene Sydtønder og Flensborg og Flensborg bykreds. Passet havde form af et énsidet kort uden billede. Det kunne købes uden at forelægge legitimation. Den rejsende skulle blot selv påføre sit navn. Passet havde to afrivningstaloner - den ene blev afrevet $i$ paskontrollen ved indrejse, den anden ved udrejse.

Endnu en lettelse kom med en overenskomst af 3. juli 1930. Nu kunne grænseområdets beboere få en vedtegning i deres pas, som berettigede til midlertidigt at opholde sig i det andet lands grænseområde for at udøve deres erhverv. ${ }^{8}$

Tilsyneladende gik tendensen således $i$ retning af at begrænse grænsens skillende betydning for befolkningen. Men andre forhold lagde sig imellem. Magtomvæltningen i Tyskland i 1933 og den tiltagende nationale spænding i 1930'erne kom på tværs. Under de ændrede forhold følte begge lande et stigende behov for at kontrollere grænsepassagen.

Her var udflugtskortene (10-øres-passet) et problem. Efter de oprindelige regler kunne kortene købes og udfyldes af enhver dansk eller tysk statsborger uden legitimation. Det umuliggjorde al effektiv grænsekontrol, og det kunne ikke kontrolleres, at personer som var kommet ind på udflugtskort ikke herefter rejste videre nord for udflugtsområdet. Det fik fra 1933 advarselslysene til at blinke. Straks i 1933 indledte politimesteren $i$ Tønder og politiadjudanten i Aabenraa et felttog mod ordningen. Der var mange argumenter: Ret ofte blev 

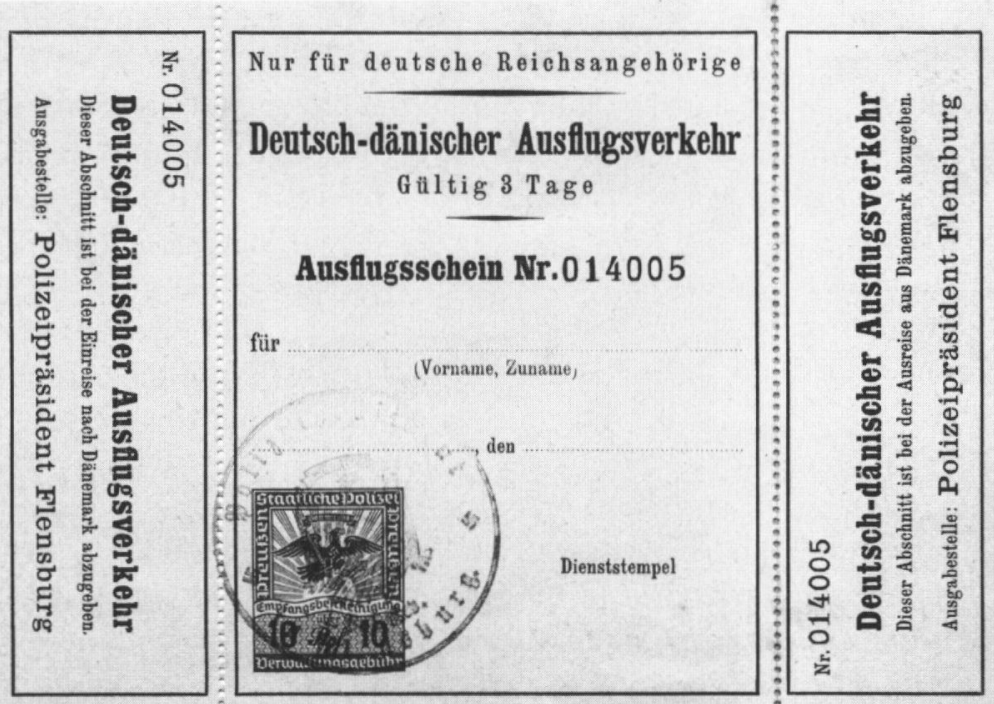

\section{Zur Beachtung!}

1. Der Ausflugsschein ist nur gültig, wenn Vor- und Zuname vom Inhaber eigenhändig und mit deutlicher Sehrift in lateinischen Buchstaben eingetragen worden ist.

2. Das dänische Ausflugsgebiet umfaßt die Ämter Tondern, Apenrade und Sonderburg.

3. Der Grenzübertritt kann an jeder Grenzübergangsstelle mit Paßabfertigung innerhalb der Dienststunden erfolgen.

4. Mißbränchliche Verwendung und falsche Angaben werden strafrechtlich verfolgt.

I 1929 blev der for at lette grænseovergangen for beboere på begge sider af grænsen indfort såkaldte "udflugtskort ", $i$ daglig tale kaldt »ti-øres pas" eller "Groschenpass". Disse kort gav let adgang til at komme over grænsen. Kortet kostede ti ore på den danske side og 10 Pfenning (en Groschen) pd tysk side. Grænsepasset havde to taloner - den ene skulle rives af ved udrejse - den anden ved indrejse. Ti-ores passet var gyldigt $i$ tre dage. Kortets forside ses her øverst, bagsiden nederst. Arkivet ved Dansk Centralbibliotek for Sydslesvig P 508-2. 
der nord for grænsen påtruffet tyske betlere, som var kommet ind $i$ landet på 3-dages pas, og det var hændt, at udviste fra Danmark var sluppet ind igen på lignende måde. Den lette adgang til grænsepassage havde angiveligt lokket mange til at tage et smut til Flensborg for at fejre drikkeorgier. En stigende forekomst af kønssygdomme i grænseegnene blev forklaret med solderierne i Flensborg. Værre var dog, at ordningen gav uonskede elementer let adgang til at komme ind $\mathrm{i}$ Danmark. Efter den nazistiske magtovertagelse måtte det frygtes, at ekstremt nationalistiske kredse $\mathrm{i}$ begge lande ville dyrke den indbyrdes kontakt endnu mere end før. Hertil kom, at ordningen gjorde det muligt for tyske politiske flygtninge at slippe ukontrolleret ind i Danmark. Gennem kolleger i politiet i Flensborg var det danske politi bekendt med tilfælde, hvor en dansk hjælper var taget over grænsen på udflugtskort udfyldt i eget navn, havde overladt dette til en tysk flygtning, og at de to derefter var passeret grænsen nordpå, flygtningen ved hjælp af udflugtskortet, den danske ven på sit medbragte lovlige danske pas. Politiet i Flensborg berettede også, at danske statsborgere, som ikke var velsete i Tyskland, var udrejst på udflugtskort med fingeret navn. Syd for grænsen havde de derpå indsamlet oplysninger eller uddelt propagandamateriale og var uantastet vendt tilbage til Danmark.

Det var i de korrekte politifolks øjne uheldigt. „Enhver kontrol med hensyn til udlændinges passage over den dansk-tyske grænse er umuliggjort, i realiteten er al virkelig paskontrol ophævet, idet ikke velsete udlændinge vil være i stand til uden store vanskeligheder ved hjælp af udflugtskort at passere de danske grænseovergangssteder «, hed det i politiadjudantens skrivelse til chefen for statspolitiet den 18. juli 1934. På et tidspunkt, "hvor brydningerne her i grænselandet foranlediget af udviklingen sydpå er meget stærke og hvor herværende yderliggående tysk-nationale kredse står i nær kontakt med den nazistiske bevægelse syd for grænsen « var det uheldigt ikke at kunne føre kontrol med grænsepassanterne. På dansk side var en begrænsning af trafikken hen over landegrænsen nu det mest ønskelige. Derfor foresloges ordningen ophævet. Alle de sønderjyske politimestre var enige med politiadjudanten, og i 1936 foreslog den danske regering ordningen ophævet. ${ }^{9}$

Meget talte for en sådan ophævelse. På tysk side var ordningen ikke blevet overholdt efter sit bogstav siden 1933. Efter magtomvæltningen blev kortene kun udstedt af politipræsidiet i Flensborg og 
fældet var. I alt fald blev rejser nordpå over grænsen tilladt $i$ vid udstrækning. Danske funktionærer og personligheder i det danske foreningsliv i Sydslesvig kunne passere grænsen. Hvert år gennemførtes et anseligt antal forenings- og grupperejser nordpå. Danske spejdere tog på lejr, skolebørn på sommerferieophold, unge tog på efterskole og højskole og mødre med børn og gamle på rekreationsophold. En lille kreds af fremtrædende danske havde ret uhindret adgang til at passere grænsen og f.eks. benytte deres sommerhuse i Danmark. Tilsvarende fik Sydslesvig helt til krigens slutning besøg af kunstnere og foredragsholdere og grupper af danske kulturelle og nationale foreninger nordfra. Også under Danmarks besættelse 194045 var det således muligt at passere grænsen med henblik på opretholdelse af det danske kulturelle og folkelige arbejde i Sydslesvig. ${ }^{12}$

\section{Den kaotiske befrielsesmåned}

Alt dette blev anderledes ved den tyske kapitulation i maj 1945. Den 5. maj overtog frihedskæmpere grænsevagten på dansk side. Bevæbnede til tænderne med våben taget fra de bortdragende tyske tropper besatte frihedskæmperne grænsen i henved en 14 dages tid. ${ }^{13}$ En hovedopgave var at sikre, at krigsforbrydere og belastede nazister ikke kunne undslippe deres velfortjente straf, tyske sydfra via Danmark og danske nordfra ind i Tyskland. Ingen i Danmark ønskede ej heller, at nogle af de tidligere tyske soldater, som i disse dage blev sendt sydpå, atter skulle vende tilbage, fordi de $\mathrm{i}$ besættelsesårene havde fået en vis tilknytning til landet. Også det store flygtningepres, som i tiltagende grad dukkede op syd for grænsen, stillede krav om ekstra årvågenhed. Det var i sandhed kaotiske dage. I en kort fase var det nærmest frihedskæmperne, som rådede over grænsepassagen.

Over for denne improviserede grænsevagt var det ikke let at slippe igennem. Helt lukket var der dog ikke for den pågående med særlige forbindelser. Den 8. maj kørte den danske skoleinspektør Svend Johannsen i bil fra Slesvig til Flensborg. Malende har han beskrevet det $\mathrm{i}$ sine dagbøger. Med Dannebrogsvimpel på bilen gik det mod grænsen "i ret god fart, og uden at formindske den, blev bommen straks hævet og spærreposterne trådte tilbage. Jeg kunne ikke lade være med at råbe et kraftigt hurra, da jeg passerede grænsen og parkerede bilen overfor toldkontoret. Det første indtryk var overvældende og ufatteligt, fuldt som der var af danske frihedskæmpere, bevæbnede til tænderne.« Jo- 


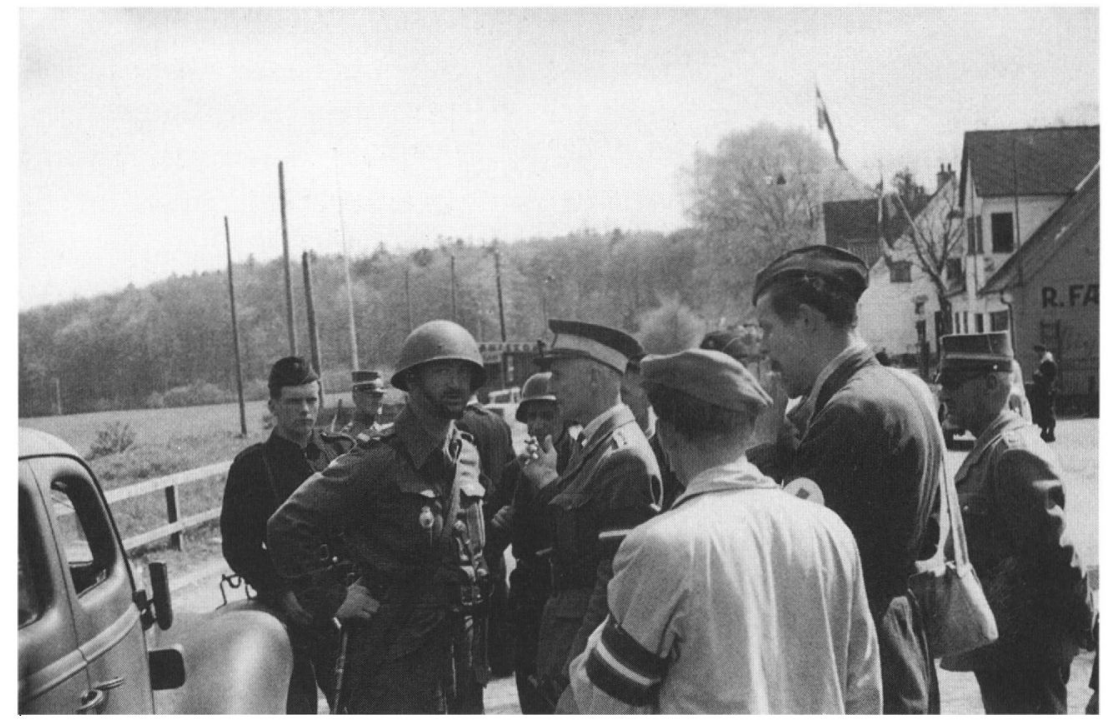

Kaptajn Bartholdy $i$ samtale med en officer fra den danske brigade, omgivet af frihedskæmpere og grænsegendarmer. Foto Svend Johannsen maj 1945 i Dansk Centralbibliotek for Sydslesvig.

hannsen opsøgte kaptajn Bartholdy "for at spørge, om der var noget $i$ vejen for at jeg kunne passere frihedsvagtens pigtrådsspærringer. »Til enhver tid « svarede han. « Johannsen kørte så op til korsvejen lige nord for grænsen "for at se de bortdragende tyskere, der kom i biler, blive afvæbnede og berøvet deres vogne. Om det så var generaler, måtte de af med pistolen ... Der var mange mennesker på benene, navnlig unge, næsten alle forsynede med Dannebrogsflag og som med stormende begejstring hilste ethvert engelsk køretøj, der kom sydfra. Men forøvrigt er det vist umuligt for mig at beskrive den stemning, der åndede og de følelser, der strømmede gennem mig selv. Da jeg jo ikke var i besiddelse af de foreskrevne papirer, nemlig dansk pas, havde jeg en del besvær med stadig at skulle forklare mig overfor de mange frihedskæmpere, der stadig standsede mig. Jeg tør nok antyde, at det ville være noget af et kunststykke for en, der ikke havde rent mel i posen, at slippe igennem den kontrol.«

Også de følgende dage lykkedes det Johannsen at slippe over grænsen. Den 11. maj »var der ingen vanskeligheder af nogen art«. Johannsen kørte til »Gråsten, tilbage ad Strandvejen. En vidunderlig oplevelse. Fjorden fyldt med skibe af enhver art. Blev standset af to 

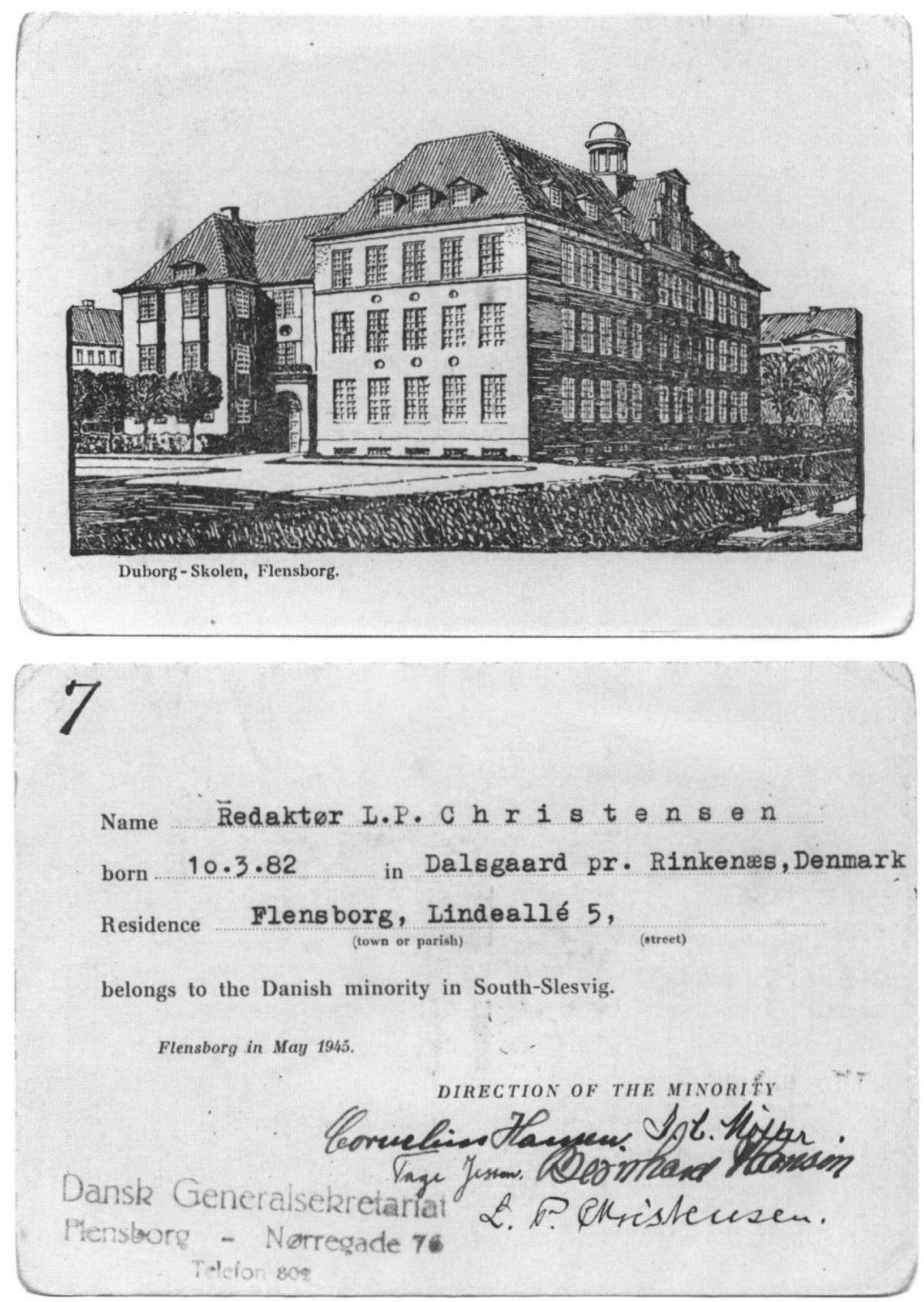

I den kaotiske tid lige efter den tyske kapitulation var det svart at fá tilladelse til at passere grænsen. I Sydslesvig udstedte det danske mindretals organisationer legitimationskort, hoor de bekræftede, at indehaveren tilhørte mindretallet. Sådanne kort kunne benyttes bl.a. $i$ forbindelse med onske om at passere grænsen. Her legitimation fra maj 1945 på engelsk til redaktor L. P. Christensen, Flensborg Avis. Arkivet ved Dansk Centralbibliotek for Sydslesvig P 166-1. 
meget unge frihedskæmpere med maskinpistoler $i$ anslag. Gad vist hvor mange vådeskud der sker i denne tid, "skrev han i sin dagbog. ${ }^{14}$

Under sådanne forhold herskede der ikke så lidt uklarhed. Men snart ændredes forholdene. På den tyske side overtog englænderne den 11. maj grænsespærringen, og få dage efter blev frihedskæmperne på dansk side sendt hjem. Folk fra Den Danske Brigade i Sverige og den danske livgarde varetog nu opgaven. Endnu var kompetenceforholdene dog uklare. Syd for grænsen var der for alvor opbrud, og her var det livsvigtigt for det gamle danske mindretal og den fremvoksende danskorienterede bevægelse at sikre en let forbindelse hen over grænsen. Fra rigsdansk side blev frihedskæmper Lyck fra Sonderborg stationeret i Flensborg med opgave at danne forbindelsesled mellem danskerne og den britiske militærguvernør. Lyck holdt i maj 1945 kontor på Duborg Skolen og tog sig særlig af at udstede passersedler. Mindretallet trykte legitimationskort med engelsk tekst på den ene side og underskrift af 5 ledende medlemmer af det danske mindretal - den senere overborgmester J.C. Møller, redaktør L.P. Christensen, Skoleforeningens formand Cornelius Hansen, rektor for Duborg Skolen Bernhard Hansen og Den slesvigske Forenings formand Tage Jessen. Underskriften bekræftede, at indehaveren tilhørte det danske mindretal. Kortene var bl.a. tænkt som et hjælpemiddel ved grænsepassage. Mindretallet ønskede, at kortene skulle have en vis autorisation fra engelsk side. Det lykkedes også en tid lang. Gentagne gange frem til 2. juli slap Svend Johannsen over grænsen med den helt specielle passerseddel. ${ }^{15}$

Men de uregulerede forhold gjaldt kun en kort overgangstid. For englænderne var det vigtigt at få kontrol med grænsen. Den 4. juli 1945 klappede fælden i for Svend Johannsen. Han blev kaldt til forhør i det britiske Field Security Police, som varetog sikkerhedsovervågningen ved grænsen. Her lød beskeden, at skolelederens legitimation til grænsepassage havde været utilstrækkelig, og da hans redegørelse ikke blev godtaget, blev han arresteret en dags tid. Frem til september fik han tilhold om ikke at forlade Slesvig by. Ved grænsen nægtede det engelske personale at have godkendt hans certifikat. ${ }^{16}$

\section{Grænsen lukkes}

Sv. Johannsens historie er ikke typisk. I al almindelighed sænkede der sig fra maj 1945 et jerntæppe mellem Vesterhavet og Flensborg Fjord. 
Grænsen blev nærmest hermetisk lukket. Folk som sydfra tilfældigt var havnet nord for grænsen før maj 1945, blev afskåret fra at komme tilbage. Den 83-årige dansksindede Hans Madsen, som siden 1888 havde boet i Flensborg, hvor han gennem mange år havde været direktør for gasværket, var i april 1945 tilfældigt på besøg hos en datter på Kolding-egnen. Her strandede han, og endnu i oktober 1945 havde han ikke fået lov at vende hjem. Danske sydslesvigere, der fra engelsk krigsfangenskab var havnet $\mathrm{i}$ Danmark, måtte vente $\mathrm{i}$ månedsvis på at kunne slippe over grænsen.

Hjemmetyskere i Nordslesvig blev også lukket inde. Den tyske biblioteksleder Hans Peter Johannsen i Flensborg var ved kapitulationen i maj 1945 på besøg hos familien i Tinglev. Det kom til at betyde, at han måtte vente til januar 1947, før grænsebommen åbnede sig. ${ }^{17}$ Det samme gjaldt for hovedparten af det tyske mindretals medlemmer. Indtil begyndelsen af 1947 var grænsen lukket. Også postforbindelsen blev standset, og f.eks. Flensburger Tageblatt måtte ikke sendes over grænsen nordpå. Først fra 1947 var der fremgang - med fornyet mulighed for at gennemføre rekreationsrejser for børn og pleje sociale og kulturelle forbindelser sydpå. Indtil disse forbedringer slog igennem kom der mange klager fra hjemmetysk side over forholdene og over angivelig tilsidesættelse $\mathrm{i}$ forhold til det danske mindretal syd for grænsen. Ønsket om at kunne genoptage en fri kulturel udveksling hen over grænsen sydpå blev et fast krav i det tyske mindretals henvendelser til myndighederne. Porten mod syd skulle åbnes, snærende pasbestemmelser skulle ophæves, lød det i mindretallets valgønsker i 1947. Ikke grænseforskydning, som ønsket gik på i mellemkrigsårene, men bevægelsesfrihed i grænseområderne og grænsenedbrydning, så grænserne mistede deres betydning, blev først i 1950'erne losenet for mindretallet $i$ nord. ${ }^{18}$

\section{Breche i den lukkede grænse}

Ønsket om fri grænsepassage var det samme for begge mindretal. For det pludseligt fremvoksende danske arbejde i Sydslesvig var det helt afgørende at skaffe mulighed for fri kulturel udveksling nordpå. Sydslesvigerne måtte have mulighed for at rejse til Danmark, og der var brug for danske funktionærer til opbygning af det danske arbejde lærere, sygeplejersker, præster o.s.v.

Efter den allerførste kaotiske tid blev det fastslået, at beføjelsen til 
MLITRY TRAVEL PERMIT 1892

TO LEAVE

GERMANY

Militarische Reise Erloubnis

zum Grenzubertritt)

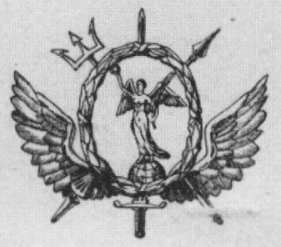

The Allied Military Authorities authorise the person named hereon to travel as stated.

Wie Aliwerien Militörischen Behorden gestatten die hierin genonnte Person die erwahnte Reise zu unternehmen):

This permit is valid only in conjunction with a valid Passport.

Diese Erloubnis ist nur quihg" wenn der Inhaber inn Besift eines gultigen Reiseposses ist)

Surname -.. CHRISTENSEN (Fomiliennoma)
(Vornamentian Names Larknz. Peter

Nationality - German

Staofsangeharigkerti)

Destination-_. COPENHAGEY
Bestimmunqsort)

Valid trom-3. $\mathrm{Cug}^{\prime} 45$ - to
(Gultig von

Passport :-

(a) Number $858 / 43$

(Reisepass) (Nummer)

(4) Date of issue 2 2 $7 .-7.43$ (Wann ausgestelit)

(c) Place of issue fLEYSBORG. (Wo ausgestelit)

TRANSIT/SINGLE/RE TURN (Durchreise/Einmal/ und Zurick)

Signature of bearer. 2. Ahrid 2 (Unterschrift des Innabers)

This permit is not an agreement to provide or an authorisation for transportation.

Diese Erloubnis ist nicht ein Vergleich zu versorgen oder en Genehmugung fur Tronsport.)

\section{LARS N. HENNINGSEN}

I den forste tid efter maj 1945 skulle tilladelse til at passere grænsen soges hos SHAEF - de allierede invasionsstyrker. Her ses et "Exit Permit « fra august 1945 til redaktor L.P. Christensen, Flensborg Avis, til at rejse til Kobenhavn. L.P. Christensen havde ret til gentagne grænsepassager - et sjeldent privilegium dengang. Arkivet ved Dansk Centralbibliotek for Sydslesvig P 166-1.

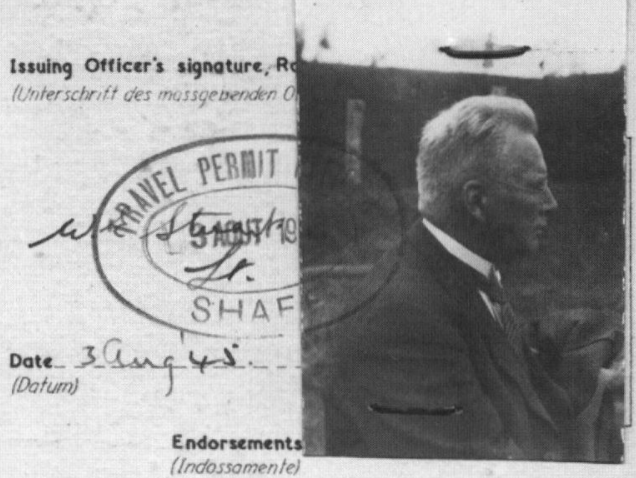

(Indossomente)

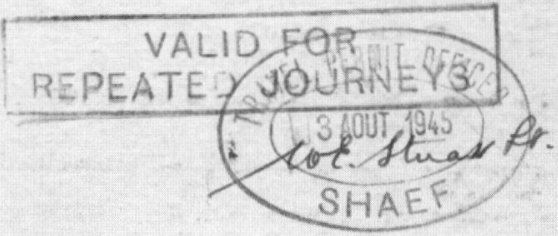


at give de nødvendige indrejsetilladelser lå hos SHAEF (Supreme Headquarters of Allied Expeditionary Forces - de allierede invasionsstyrkers hovedkvarter) i Frankfurt. Til grænseovergang krævedes et "permit « udstedt af SHAEF - og et sådant kom bestemt ikke af sig selv. I Kobenhavn sørgede en Travel permit officer for kontakten til SHAEF i Tyskland. Fra august 1945 blev grænsekontrollen i SlesvigHolsten overdraget til de lokale besættelsesmyndigheder i Plön og Flensborg. Det betød, at ansøgere om tilladelse til indrejse i SlesvigHolsten måtte løbe spidsrod mellem en hel række af institutioner, $i$ Kobenhavn, i Plön-Flensborg, i Berlin og London.

Anmodninger om lettelse af grænsepassagen blev et fast punkt $i$ henvendelser fra Sydslesvig lige fra juni 1945. I en skrivelse af 8 . juni fremsatte mindretalsledelsen ønskerne om fri grænsepassage. Beretninger og breve fra Sydslesvig havde pasproblemer næsten som et fast omkvæd i denne tid: Der var brug for fri indrejse for danske politikere, journalister og foreningsfolk nordfra og for fri passage over grænsen til personer i mindretallets tjeneste og til foreningsformænd. Til de nye præsteembeder var der masser af ansøgere, men klagen lød, at det var umuligt at få dem over grænsen. Skolevæsenet var i voldsom vækst, men lærerne kunne ikke få indrejsetilladelse. Biblioteksvæsenet havde brug for forøgelse af bogbestanden, men hverken bøger eller nyt personale kunne komme nordfra. Selv når det lykkedes varede ventetiden på pas ofte i måneder. Ønsket gik på, at sagsbehandlingen skulle henlægges til en lokal myndighed i grænselandet. ${ }^{19}$ Klagerne over grænsespærringen og forbudet mod forsendelse af post over grænsen blev opsummeret $\mathrm{i}$ mindretallets henvendelse til den danske regering 19. november 1945.

Det danske udenrigsministerium bakkede ønskerne op, først overfor SHAEF og, da kontrollen med Slesvig-Holsten i eftersommeren 1945 var overgået til den britiske Rhinhærs 8. korps, til både den engelske og den amerikanske gesandt i København og de britiske militærmyndigheder i Flensborg og Plön. Det lykkedes da også at opnå tilladelse til grænsepassage for flere grupper af funktionærer, skolebørn, mødre med børn, spejdere, gamle og syge. ${ }^{20}$

Henvendelserne bar frugt. Den 4. september 1945 åbnedes et fælles britisk-dansk paskontor på Søndertorv i Flensborg. Kontoret var tænkt som en håndsrækning til det danske arbejde og skulle medvirke til at lette sydslesvigernes adgang til at komme over grænsen.

I april 1946 kom det næste lille fremskridt. For områdets beboere 


\section{№ 78669}

\section{ALLIED \\ EXPEDITIONARY FORGE PERMIT}

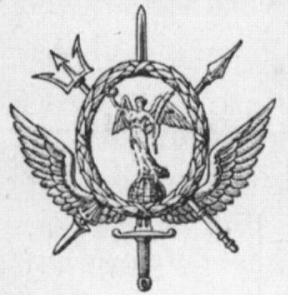

The bearer of this permit has the permission of the Supreme Commander Allied Expeditionary Force to enter the Zone of the Allied Forces in

Le titulaire est autorisé d'entrer dans la Zone de lismée.Allikéen

\section{GERMANY}

IN

ALLIED OCLUPATION

This permit must be produced when required together with the bearer's identity document.

Ce permis doit être présenté à toute demande avec le document d'identité du titulaire.

\section{LARS N. HENNINGSEN}

SHAEF kontrollerede fra maj 1945 indrejser fra Danmark til Tyskland. Her indrejse-tilladelse - ventry-permit" - til den senere direktor for Grænseforeningen O.M. Olesen september 1945. Arkivet ved Dansk Centralbibliotek for Sydslesvig $P 403$.

\section{MHAEF MISSION (DEEMARR)}

Date

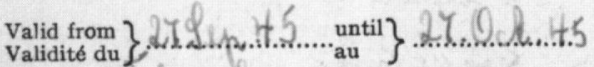

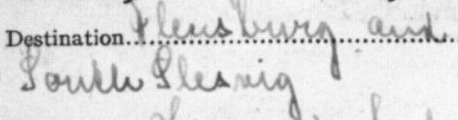

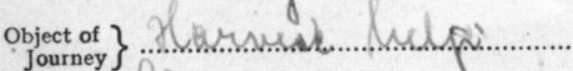
Occupation... D.unchens.

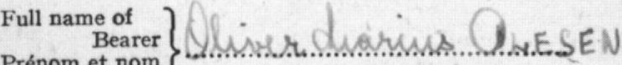
Prénom et nom du Titulaire

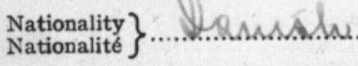

Number and Type of Identity Document A.

Ministry or Dept. \} Whase whand Signature $\left\{\begin{array}{l}\text { of Bearer } \\ \text { du Titulaire }\end{array}\right\}$

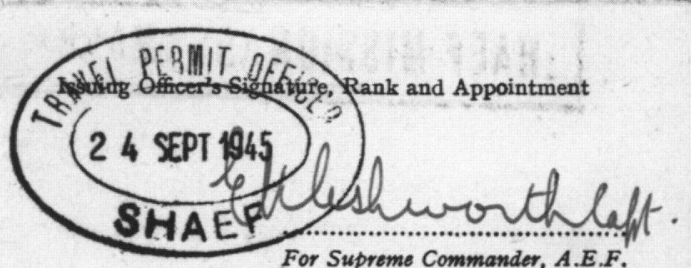

For Supreme Commander, A.E.F.

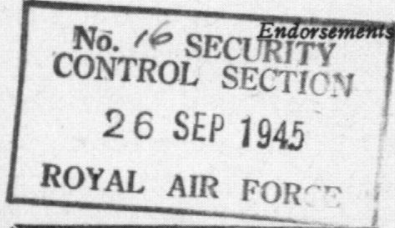

Travel Security (Germany)

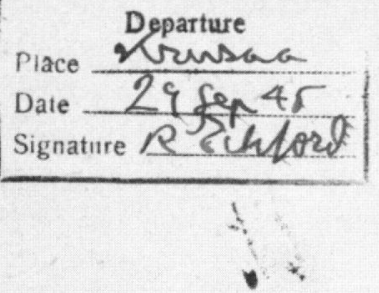


DANSK-BRITISK PASKONTOR

Sendertory 13-14

FLENSBORG
Flensborg, d. $\quad 8.1 .1947$.

\section{5.}

\section{Anledning af Deres hertil indgivne Andra- gende af ...........11.1946..... beklager man at maatte meddele, at det ansøgte ikke har kunnet imødekommes.}

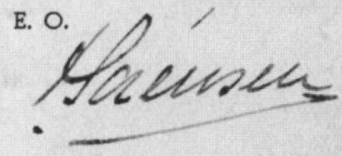

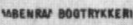

Meddelelse fra Dansk-Britisk Paskontor $i$ Flensborg. Kontoret bidrog fra oprettelsen $i$ september 1945 og ind $i$ 1950'erne $i$ hoj grad til at lette sydslesvigernes indrejsemuligheder til Danmark. Arkivet ved Dansk Centralbibliotek for Sydslesvig.

blev det muligt at få et grænsepas (Military Frontier Pas) gældende besøg i det nære område på den anden side af grænsen. For nordslesvigere skulle ansøgning ske gennem politikommandøren i Aabenraa, hvorfra sagen gik videre til det fælles britisk-danske paskontor i Flensborg. For sydslesvigere skulle henvendelse rettes til det fælles britisk-danske paskontor, som kunne udstede pas efter forudgående godkendelse hos den lokale britiske militærguvernør. For alle øvrige ansøgere om grænsepassage skulle tilladelse (»Military Entry Permit « gældende rejse ind i Tyskland, »Military Exit Permit« gældende rejse ud af Tyskland) af danskere søges gennem det britiske paskontor i Kobenhavn, af tyskere gennem den lokale militærregering i Tyskland. ${ }^{21}$ Yderligere skulle danskere have udrejsevisum i Udenrigsministeriet.

Det særlige paskontor var således et fremskridt. Men tilfreds var mindretalsledelsen i Sydslesvig endnu ikke. Nåleøjet viste sig at være de lokale britiske militærmyndigheder i Flensborg. Mindretalsledelsen syd for grænsen følte sig chikaneret. Generalsekretær Frants Thygesen lagde i sine månedlige redegørelser ikke skjul på sin opfattelse. I juli 1946 skrev han: "Grænsekontrollen, der naturligvis rammer 
danskheden langt hårdere end tyskerne, er stadig meget skarp. Friseren Oldsen fik nægtet pas for at kunne forhandle i Nordslesvig om unge friseres højskoleophold; en sydslesvigsk kvinde, der skulle have talt på Skamling 30. juni, fik også nej; de mange lærere m.fl. i det danske arbejde i Sydslesvig kan ikke engang få bevilget 1 månedlig rejse over grænsen, skønt mange af dem har måttet efterlade familien nord for grænsen, og de alle har god brug for at kunne hente noget nord for grænsen både til sig selv og til deres skole. Rejser nordfra er lige så besværlige. Nogle præster, der skulle besøge Sydslesvig for at tale om kirkelige emner o.lign., fik et Nej; ligeledes et dilettanthold fra Padborg. De indrejsetilladelser, der bevilges, kommer næsten alle i allersidste øjeblik, hvad der besværliggør alle arrangementer. Generalsekretariatet fik 4. juni afslag på ansøgning om indrejsetilladelse for 4 amtssekretærer. Englænderne ønsker at hæmme forbindelsen mellem Danmark og Sydslesvig. Typisk er følgende udtalelse: „Disse ansøgninger bliver alt for talrige. Sydslesvigsk Forening bør opfordres til selv at sørge for underholdning og ikke være afhængig af hjælp udefra (d.v.s. fra Danmark!).« I august 1946 var generalsekretærens tone endnu mere anklagende: »Folk der kommer nordfra for at arbejde $\mathrm{i}$ danskhedens tjeneste, er ude for en grov behandling, navnlig fra militærguvernøren i Flensborg, oberstløjtnant Lindsey Young, der er ved at blive danskhedens fjende nr. 1. Så mange som muligt nægter han pas, bl.a. 42 lærere til Flensborgs danske kommuneskoler, skønt de nye afdelinger er godkendt af englænderne forlængst og pasansøgning indgivet i april. Andre der har fået indrejsetilladelse fra det engelske paskontor i Kobenhavn, får at vide, at den officer, som har underskrevet pas der i et halvt år, ikke er kompetent til det, hvorfor de må rejse hjem igen ... Pasordningen bliver mere og mere besværlig og afhængig af militærregeringens luner ...«.22

De mange klager bør dog ikke skjule, at de særlige grænsepas (Military Frontier Pas) reelt blev den ventil, som gav det fremvoksende danske mindretal bedre muligheder for trods grænsespærringen at pleje de vigtige kulturelle forbindelser nordpå. Grænsepassene blev udstedt til medlemmer af mindretallet, og i praksis blev de benyttet til rejser over hele Danmark, ikke kun til Nordslesvig. ${ }^{23}$ Men muligheden blev forbeholdt snævert afgrænsede grupper. Kun ledende foreningsfolk, spejdere og skole/børnehavebørn på fælles ferierejser, højskoleelever, gamle og syge og mødre med børn på rekreationsrejse - og danske funktionærer i mindretallets tjeneste havde en chance. 
For alle almindelige borgere vedblev grænsen at være hermetisk lukket. »Personer, som ikke opfylder betingelserne, vil ikke kunne komme i betragtning «, hed det lakonisk. ${ }^{24}$

Paskontoret blev således et fremskridt for mindretallet. Rent faktisk gav det den sydslesvigske befolkning en væsentlig bedre stilling med hensyn til rejser til Danmark end grænsebefolkningerne i Tyskland i øvrigt. Uden gebyr blev der udstedt grænsepas til sydslesvigeres rejse i folkeligt-kulturelt øjemed til hele Danmark. Disse fordele blev gentagne gange taget $\mathrm{i}$ forsvar over for briterne af de danske myndigheder. Briterne fastsatte årlige kvoter, hvorefter de enkelte dansk-kulturelle foreninger kunne sende et bestemt antal medlemmer over grænsen. Det skete på fællespas. For året 1948/49 så de tilladte kvoter sådan ud: $:^{25}$

$\begin{array}{lr}\text { gamle } & 1.200 \\ \text { mødre med børn } & 350 \\ \text { feriebørn } & 11.000 \\ \text { spejdere } & 400 \\ \text { skakklubber } & 150 \\ \text { atletikhold } & 750 \\ \text { fodboldhold } & 250 \\ \text { håndboldhold } & 450 \\ \text { badmintonhold } & 40 \\ \text { folkedansere } & 450 \\ \text { kor } & 250 \\ \text { orkestre } & 150 \\ \text { amatørteatre } & 30 \\ \text { husmoderforeninger } & 50\end{array}$

Grænsepas blev også udstedt til ledende enkeltpersoner i Sydslesvigsk Forening. Passene skulle bidrage til at opretholde nødvendige kulturelle forbindelser i Danmark. Politik måtte der ikke drives under besøgene i Danmark. Derfor hændte det, at passene atter blev inddraget, når det forlød, at de pågældende havde holdt en politisk tale $\mathrm{i}$ Danmark eller på anden måde indladt sig på politik. I marts 1948 inddrog englænderne f.eks. landdagsmand Hermann Clausens grænsepas, da det blev kendt, at han havde holdt foredrag og radiotaler under besøg i Danmark. Det var et brud på vilkårene for udstedelsen 
af hans grænsepas. Hvis han ville holde tale under besøg i Danmark, måtte han søge et ordinært Entry and Exit Permit. ${ }^{26}$

For »almindelige folk « var det straks værre at opnå grænsepassage. "Folk der hverken var spæde, skolebørn, tuberkuløse, badmintonspillere eller lignende, havde meget små chancer for at komme til Danmark, selv om de som danske sydslesvigere havde aldrig så gode grunde for det", hed det spidst fra generalsekretær Frants Thygesen i $1950 .{ }^{27}$

Formuleringen afspejler de mange klager som indløb over forholdene. I april 1947 klagede f.eks. et gammelt SSF-medlem i et brev til generalsekretæren: "Vi er få hundrede, men virkelig gamle medlemmer, veteraner af den 1920 til Slesvigsk Forening omdøbte Vælgerforening, som nu har ventet to år på at få lov til at besøge venner og familie $\mathrm{i}$ gamle Danmark. Det skorter ikke på venlige indbydelser, der ytrer forundring over, at kun folk med protektion kan få tilladelse til en tur nord for grænsen, når de er under 60 år gamle. Når man så oplever, at svimlende gagerede kontorchefer og funktionærer, der vanskeligt er at få $i$ tale personligt for små medlemmer, kan passere grænsen, føler man sig tilsidesat. $\ll^{28}$

\section{Grænsens jerntæppe}

Dette var den almindelige opfattelse af grænsen i disse år. Jerntæpper var et efterkrigsfænomen, som ikke kun var kendt $i$ andre dele af Europa - også den dansk-tyske grænse havde udviklet sig til et jerntæppe, mente en L. Kock fra Høruphav i et læserbrev i dagbladet »Sønderjyden« den 23. december 1947. Det havde befolkningen fået bitterligt at mærke, mente han. Gennem hele den prøjsiske tid havde Sønderjylland op til Kongeåen oplevet en levende befolkningsudveksling fra nord til syd og omvendt. Sønderjyder havde uddannet sig sydpå og fundet både ægtefælle og levebrød dernede. Andre var som embedsmænd blevet forflyttet sydpå. Sydfra var tjenestepiger kommet til Nordslesvig og havde giftet sig. Mange sønderjyder havde på den måde fået familie på begge sider af grænsen. Nu efter krigen sad familiemedlemmer skilt af den lukkede grænse og længtes efter at se hinanden. "Mange har søgt om tilladelse til et besøg af de nærmeste slægtninge, men langt de fleste vedkommende har fået et afslag ... Der kan nævnes tilfælde, hvor en gammel fader - en gammel moder lå for døden og deres eneste sidste ønske var at måtte få lov til 
at se og tale med deres nærmeste - en søn eller datter - på den anden side af jerntæppet - men tilladelsen blev ikke givet. At søge til en begravelse er nytteløst, da den kære afdøde forlængst er under jorden, inden afslaget kommer på ansøgningen. « $\mathrm{Nu}$ var man kommet til tredje jul efter freden. "Hvor længe skal det endnu vare, inden tæppet løftes en lille smule? Ja, bare så meget, at vi kan få lov til at besøge en fader, en moder, en søster eller broder en eller to gange årligt? « Kock foreslog, at alle i Sønderjylland, der havde nære slægtninge på den anden side, kunne samles om et andragende med underskrifter med »en julebøn: Rul jerntæppet en lille smule op, giv os endelig lov til en gang i nær fremtid at gense vor nærmeste familie på den anden side af grænsen, " sluttede Kock sit indlæg. ${ }^{29}$

Her tegnes med sorte streger - og faktisk var der også mange regler at overvinde. Forældre skulle f.eks.være over 70, senere nedsat til 60 år, og den pårørende skulle have boet $\mathrm{i}$ længere tid $\mathrm{i}$ det andet land, før visum kunne gives. I Justitsministeriet fremhævede departementschef Eivind Larsen i 1949, at der var gode grunde til at være tilbageholdende med tyske onsker om ophold i Danmark. Hvis man gav »indrejse til alle blot ikke-kompromitterede tyske statsborgere, ville Danmark hurtigt være oversvømmet af dem, og det ville være vanskeligt at komme af med dem ... «. ${ }^{30}$ Hertil kom forsigtigheden over for »landssvigere«. Flensborg-paskontoret udførte omhyggelige undersøgelser af hver enkelt ansøger. Personer som havde stået i nazistpartiet blev afvist. I 1950 førte det til en skarp reaktion fra en afvist Flensborger. Flere gange havde han stillet andragende om at få lov til at besøge familie i Sønderjylland, senest til en vigtig familiefest. Hver gang var han blevet afvist p.g.a. tidligere medlemskab af NSDAP. Nu 5 år efter kapitulationen var hans tålmodighed opbrugt, og $\mathrm{i}$ vrede udmeldte han sig af de danske organisationer SSF og SSW..$^{31}$

Også for erhvervslivet var det svært at overvinde grænsespærringen. I 1948 ønskede f.eks. erhvervsfolk fra Nordslesvig at genoptage forbindelserne sydpå og besøge messen i Flensborg. Det var kompliceret. Der skulle foreligge gyldigt pas, til dette skulle gennem det danske politi søges om udrejsevisum. Når dette var i orden kunne der søges om indrejsetilladelse hos Allied Military Permit Office i København, ledsaget af detaljerede oplysninger om messe, varer, firmaer, rejserute. Gebyret var betydeligt, der skulle foreligge anbefalinger fra erhvervsorganisationer og evt. tilladelse blev kun givet til firmaers chefer, ikke til personale. ${ }^{32}$ 
Rejser nordfra hørte i den første tid ikke under britisk-dansk paskontor. Til danske statsborgere skulle tilladelse $i$ reglen gives af de britiske myndigheder og måtte som regel cirkulere mellem det engelske pas-kontor (Military Permit Office) i den britiske militærmission på Dagmarhus i København, de britiske militærmyndigheder i Plön/Kiel, evt. den allierede kontrolkomité i Berlin og Foreign Office i London. Grænseforeningen hjalp til med anbefalinger og råd, den danske forbindelsesofficer i Sydslesvig søgte at støtte sagerne, og ikke så sjældent kom sagen helt op på Udenrigsministeriets niveau. Det var i sandhed både tidrøvende og kompliceret.

Frem til 1. april 1946 gjaldt spærringen også post og pakker. Organisationer og personer i Sydslesvig var henvist til at lade post nordfra adressere til en adresse lige nord for grænsen, ofte Gråsten Banks afdeling i Kruså, hvor posten så kunne afhentes - hvis det da var muligt at komme over grænsen. Det var i disse år Gråsten Bank spillede en stor rolle som dansk postboks og adresse for de danske aktører i Sydslesvig. "Grænsegængere " med tilladelse til at passere grænsen havde altid nok at gøre med at udføre kommissioner for mindre heldige bekendte.

Tilladelsen til at sende post over grænsen fra 1. april 1946 var en forbedring, som straks blev benyttet. »Da det endelig er blevet tilladt at sende breve over grænsen, vil vi dog give et livstegn fra os, « hedder det $i$ et brev fra Holbøl til gårdejer Meta Röh i Jaruplund den 18. april 1946. ${ }^{33}$ Nordfra kunne der skrives på dansk, men ikke den anden vej; fra Sydslesvig skulle besættelsesmagternes sprog engelsk, fransk eller russisk, eller tysk, benyttes, og frem til 1. marts 1948 var brevene tilmed underkastet britisk censur. For de udsendte danske, som var taget til Sydslesvig netop for at gøre en indsats mod alt tysk, var det noget af en overvindelse at skulle skrive hjem på tysk, hvis de ikke beherskede et af de andre sprog. "Mor fældede tårer over at jeg var nødt til at skrive til hende på tysk «, konstaterede den danske lærer Jørgen Pors i sin dagbog i Flensborg i december $1946 .{ }^{34}$ Han var jo ellers ude i danskhedens tjeneste, så her var der tale om en ubehagelig sprogtvang. Telefonere over grænsen kunne man selvfølgelig heller ikke. Der var ikke andet at gøre end om muligt at køre over grænsen og telefonere fra den danske side. Først fra 1. april $1947 \mathrm{blev}$ der igen åbnet for telefon og telegraf hen over grænsen, i første omgang dog kun til forretningsmæssig brug. Året efter kom lettelser i telefontrafikken i en $50 \mathrm{~km}$ 's zone på begge sider af grænsen. ${ }^{35}$ 
Frants Thygesen, generalsekretær for Sydslesvigsk Forening 194556. I disse år skrev han utallige indlæg og breve $i$ bestræbelserne pa at lette grænsepassagen for befolkningen syd for grænsen. Foto $i$ Dansk Centralbibliotek for Sydslesvig.

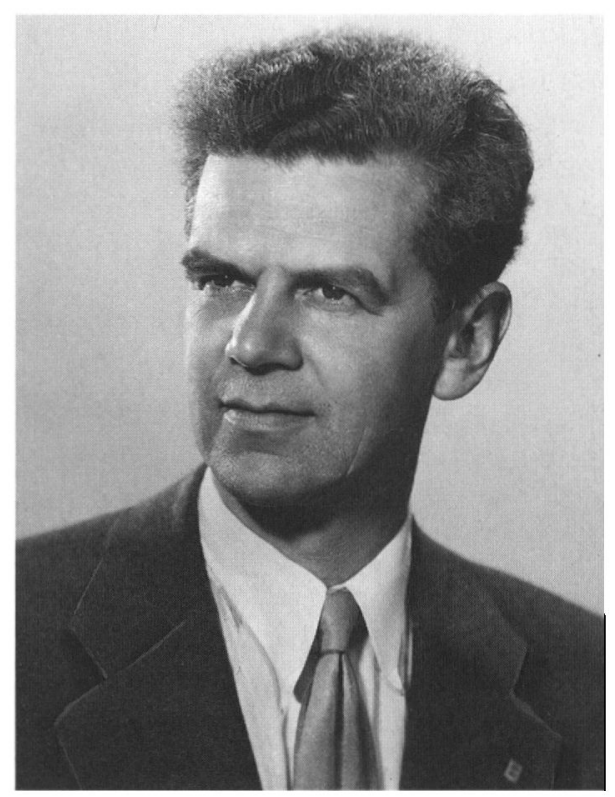

\section{Generalsekretæren, lærerne og bibliotekaren}

Vi har nu hørt om de regler, som lidt efter lidt blev etableret for trods alt at muliggøre kontakter befolkningerne imellem. Men hvordan blev den generelt vanskelige grænsepassage oplevet af den enkelte? Nogle eksempler må være nok til at give et indtryk:

Den netop nævnte generalsekretær Frants Thygesen var selv en af dem, der havde følt hvor svært det var at få lov til at passere grænsen i den første efterkrigstid, da forholdene endnu var uafklarede. I begyndelsen af juli 1945 blev han fra en stilling i Indenrigsministeriet $i$ København ansat som SSFs generalsekretær i Flensborg. Det betød dog ikke, at han straks kunne tage plads i chefstolen på Flensborghus. Med den hermetisk spærrede grænse var der lang vej.

Hos det danske politi søgte Thygesen om udrejsetilladelse. Fra politiet gik anmodningen til visumkontoret i Udenrigsministeriet. Hos SHAEF på Dagmarhus i Kobenhavn blev der søgt om tilladelse til indrejse til Tyskland. Her lød svaret, at instrukser fra SHAEF i Frankfurt hindrede afdelingen $i$ at give indrejsetilladelse til nogen. Udenrigsministeriet blev så bedt om at hjælpe, og sagen gik til Foreign Office $\mathrm{i}$ London. Lige meget hjalp det. Efter en måneds ventetid var 
grænsen stadig spærret. Så bad Thygesen om hjælp hos politikommandør Brix i Aabenraa, som netop i de dage stod foran at oprette det dansk-britiske grænsepaskontor i Flensborg. Grænseforeningen tog sig også af sagen, således som den i øvrigt måtte virke som sagfører for utallige andre i disse tider. "Grænseforeningen gør alt hvad vi kan. Men englænderne er jo ikke til at hugge eller stikke $i$, " skrev Grænseforeningens erfarne formand Holger Andersen til Thygesen den 1 . september.

Måske virkede det alligevel. I alt fald kom der en indrejsetilladelse den 5. september, og Thygesen kunne tage til Flensborg. Men kun for en kort bemærkning. Nu kom der nemlig problemer med passet, og generalsekretæren måtte fortrække til Kollund. Atter blev Udenrigsministeriet i København involveret - og først i december var pasvanskelighederne løst. Den 17. december 1945 kunne Thygesen langt om længe for alvor tage fat i Flensborg. ${ }^{36}$ Konklusionen er klar: Grænsepassage var sandelig ikke en selvfølgelighed $i$ de dage.

Thygesen var ikke den eneste, der mærkede grænsens dybe skel. I oktober 1945 begyndte lærer Martin Mortensen fra Sønderborg opbygningen af det danske skolearbejde i Kappel. Han havde opnået pas til gentagne grænsepassager og kunne en tid frit tage frem og tilbage til Sønderborg. Men i april 1946 skulle han sende passet til København, og det kom tilbage uden fornyelse. Det krævede et ekstra fremstød via paskontoret $\mathrm{i}$ Flensborg - indtil han opnåede fornyelse med ret til at rejse over to gange om måneden i et halvt år. ${ }^{37}$

For nogle lykkedes det nok at komme ind i Sydslesvig og begynde arbejdet - men det var på »enkeltbillet« uden ret til tilbagerejse. Det gav både hjemve og usikkerhed. Tønning-læreren Anna Holmgaards eksempel mødte vi i indledningen, og mange oplevede det samme som hun.

Den danske lærer Jørgen Pors, som var sluppet gennem nåleøjet til Flensborg i 1946, kendte også til problemerne. I december vidste han ikke, om han kunne komme over grænsen for at holde jul med familien hjemme. I sin dagbog skrev han: »Nu er der kun en snes dage til juleferien. Tæller nu dagene. Forhåbentlig får vi visum. Det vil ikke blive morsomt at holde jul uden Inger og børnene. Jeg længes snart efter at se dem.« Heldigvis gik håbet $\mathrm{i}$ opfyldelse. Den 21. december tog han hjem. I dagbogen lyder det sådan: "Vi når grænsen. Vi kommer hurtigt igennem både den tyske og den danske told. En underlig glad og befriende følelse ved atter at stå i Kruså og se det danske flag. 
Den samme følelse havde man før 1920, når man kom til Vamdrup, og den samme følelse kan man få ved Dannevirke eller Ejderen, hvis Sydslesvig engang skulle blive dansk. « ${ }^{38}$ Grænsen var et reelt fænomen for generationen dengang.

På det danske bibliotek i Flensborg var grænseproblemerne også det store samtaleemne. Den 1. februar 1946 tog den nye overbibliotekar Torben Glahn fat. I den første tid kunne han frit passere grænsen, men efter en tid blev det ændret til kun hver ottende dag. Og så kom der besked om, at passet ikke gav ret til at bosætte sig. I den følgende tid måtte både Glahn og hjælperne i Grænseforeningen bruge masser af tid på pasfornyelser og besøg på paskontoret.

Mindst ligeså vigtigt var spørgsmålet om at få danske bøger over grænsen. Grænseforeningen kom ordentlig $i$ arbejde for via Udenrigsministeriet og briterne at skaffe de fornodne tilladelser. Det lykkedes - men der skulle forelægges detaljerede lister over hver enkelt bog, som blev bragt til grænsen. ${ }^{39}$

Det sinkede biblioteksarbejdet, at der skulle ventes så længe før nyansatte medarbejdere fik tilladelse til at passere grænsen. Den 1. juni 1946 blev den unge bibliotekar Birthe Andrup antaget til biblioteket. I hele 6 uger måtte hun dog vente, før indrejsevisumet var på plads. Og tilladelsen gjaldt kun rejse til Tyskland - ikke tilbage. Overbibliotekar Torben Glahn lagde ikke skjul på dette problem, da han den 14. august kørte til grænsen sammen med den nye, unge medarbejder: »Hop ind, nu klapper fælden $i$,« udtalte han. Og så kørte de afsted til grænsen.

I sin dagbog skriver Birthe Andrup om mødet med grænsen: "Ankommet i tolden i Kruså så jeg for første gang grænsepælene og de små hvide bygninger med kroen, banken, toldstedet og soldaterbarakken med det sydligste Dannebrog. Igennem den danske told kom vi - bommen gik op for bilen og ned bag den. Så kørte vi op gennem ingenmandsland og op foran den tyske told. Frem med papirer og kufferter igen! Jeg var spændt på, hvordan det gik med mine forbudne frugter: Vin, tobak, breve, billeder etc. Alt gik glat, indtil en dansker $i$ engelsk uniform, som visiterede, pludselig fandt en avisartikel om det sydslesvigske spørgsmål, som jeg havde stoppet $\mathrm{i}$ kufferten. Han så rædselsslagen på mig, og da jeg sagde, at den måtte han gerne få, så han på mig og mumlede, idet han skævede til den engelske officer: »Nej det er tusind gange værre!« og slog kufferten $\mathbf{i}$ - lige før englænderen kom til. ${ }^{40}$ 
Så tog bibliotekaren fat på dagligdagen. Men den viste sig usikker for det engelske permit muliggjorde som nævnt kun rejsen over grænsen, ikke opholdet, og uden permit til hjemrejse var gode råd dyre. "Faktum er at jeg i øjeblikket ikke må være her og heller ikke må rejse hjem, og da jeg dog må gøre en af delene bliver jeg nok før eller senere sat fast, fordi jeg ikke har gjort den anden«, skrev frk. Andrup humoristisk den 7. september. Det krævede mange besøg hos konsulatet, den lokale militærregering og tyske myndigheder før opholdet var legalt fra sidst i september. Brevene til moderen hjemme i Danmark måtte frk. Andrup skrive på engelsk. Her gav hun udtryk for, at det kunne være rart at få besøg: "I'll hope that it soon will be possibly for you to come down here and see the city and the surrounding country«, lød det 6 . oktober. ${ }^{41}$ Men den slags privatrejser var nu slet ikke mulige på daværende tidspunkt.

\section{Små skridt fremad}

Kritikken af den lukkede grænse var således udbredt i de første efterkrigsår, og flere forhold sinkede fremskridt. Ændringer kunne frem til 1949 kun ske efter aftale med de allierede magter, og på rigsdansk side levede frygten for Tyskland og tyskerne. Visumbegrænsninger blev anset som nødvendige for at hindre, at landet blev oversvømmet af flygtninge fra Sydslesvig. Slap de ind i større tal, ville det give politiet et stort arbejde, og Danmark ville blive bebyrdet med en hel del uønskede og måske direkte kriminelle elementer, mente justitsminister Helga Pedersen så sent som i december $1951 .{ }^{42} \mathrm{Da}$ der blev indført pasfrihed mellem de nordiske lande, var der også hensyn at tage her. ${ }^{43}$

Alligevel gik tendensen i retning af lettelser i grænsepassagen. Trafikken var stigende. I sin årsberetning for 1949 fremhævede politimesteren i Aabenraa fremgangen. Hvis stigningen fortsatte, kunne man øjne den dag, hvor udtrykket »den lukkede grænse« ikke passede mere. ${ }^{44}$ Fra 1949 kunne alle tyske statsborgere få udstedt almindelig rejselegitimation. Der skulle imidlertid betales gebyrer, og en indførelse af de nye legitimationer i Sydslesvig ville have betydet en forringelse af de særfordele, som vitterlig var opnået for det danske mindretal takket være det særlige britisk-danske paskontor og de militære grænsepas. I den situation lykkedes det at opnå en særordning. De særlige grænsepas blev bevaret i en lidt ændret form. Fra 1950 
kunne det dansk-britiske paskontor udstede en ny slags grænsepas. De afløste de hidtidige militære grænsepas og gjaldt for højst et år ad gangen og til rejser til familiebesøg og til personer med arbejde på den anden side af grænsen. Gebyret var kun 50 Pf. Men i modsætning til de oprindelige grænsepas, som var blevet benyttet til sydslesvigeres »kulturrejser" til hele Danmark, var der nu tale om egentlige grænsepas, kun til rejser inden for selve grænseområdet. Til rejser til det øvrige Danmark skulle der skaffes almindelig rejselegitimation, visum og britisk Exit Permit, og tilsvarende Entry Permit til rejser fra Danmark ind i Sydslesvig, og for disse skulle der betales gebyr. ${ }^{45}$

Trods bevarelsen af visse særfordele faldt ændringen ikke i god jord i Sydslesvig. Gang på gang gentog det danske mindretal sine ønsker om frihed for visum og gebyrer, ophævelse af opdelingen $i$ kategorier og genindførelse af den liberale ordning, som havde rådet i mellemkrigsårene. Der var ikke længere behov for afspærring over for Tyskland, mente Frants Thygesen. "Tiden er kommet, « udtalte han i 1950, "hvor vi må anmode om, at samkvemmet mellem de danske sydslesvigere og deres moderland bliver fritaget for den slags snævre begrænsninger. Vi er nu over 5 år fra kapitulationen, og efter den megen tale om bestræbelserne for at samle Vesteuropa kan man vanskeligt forklare sig, hvorfor vi fortsat skal slås med vanskeligheder af den art. Ved den tysk-schweiziske grænse er alle begrænsninger for grænsepas ophævet. En sådan nyordning vil utvivlsomt blive støttet af de tyske myndigheder, der stadig har vist interesse for en lettere grænsetrafik.« Også på dansk side burde myndighederne tænke i den retning: »Nationale grunde kan næppe anføres. Vi kan jo dog ikke al evighed holde grænsen mod vort sydlige naboland delvis lukket. $\mathrm{Og}$ trods alt horer man allerede nu en hel del tysk tale i Nordslesvig og Kobenhavn af gæster fra Schweiz, Luxembourg - og Tyskland. Sikkerhedsmæssige grunde kan heller ikke betyde meget, da man jo ikke længere nægter visum til gamle nazister ... Nogen oversvømmelse af sulte tyskere skal Danmark heller ikke vente. Syd for grænsen er der nok af varer, også af mad, til dem, der har penge at købe for. Danmark kan næppe have noget imod at tjene DM på turister. De fattige og sultne, som der desværre er mange af syd for grænsen, kan ikke rejse. Den eneste begrænsning, man fra dansk side kan have grund til at søge opretholdt længst muligt, er med hensyn til de mange flygtninge syd for grænsen ...«. Og selv den udelukkelse kunne ikke opretholdes ret mange år. ${ }^{46}$ 


\section{F 017862}

\section{Grenzpaß}

\section{Grænsepas}

Grænsepas udstedt til kunsthandler Hattesen $i$ Flensborg til brug for familiebesøg $i$ Nordslesvig. Gransepassene blev indført $i 1950 \mathrm{og}$ kostede kun et gebyr på 50 Pf. De blev meget brugt $i$ Sydslesvig. Da grænsepasset blev ophævet $i 1957$ var 25.000 af denne slags pas $i$ omleb. 15.000 flensborgere havde grænsepas. Arkivet ved Dansk Centralbibliotek for Sydslesvig P 337-11.
Bedingungen fïr die Anwendung von Grenzpässen

1. Der GrenzpaB berechtigt nur zu Reisen zwischen Süd- und Nordschleswig innerhalb seiner Gültigkeitsdauer.

2. Bei Aus- und Wiedereinreise muB die gleiche Grenzübergangsstelle benutzt werden.

3. Der Grenzpaß ist nur gultig in Verbindung mit einem Personalausweis.

4. Der GrenzpaB ist den ausstellenden Behörden zurôckzugeben, sobald seine Gültigkeitsdauer beendet ist oder die Bedingungen, unter denen der $\mathrm{Pa} B$ ausgestellt wurde, weggefallen sind.

5. Fâlschung, Ubertragung oder sonstiger MiBbrauch des Grenzpasses, insbesondere seine Verwendung zu anderem als dem beantragten Zweck, kann strafrechtliche Verfolgung nach sich ziehen.

6. Der Grenzpaß ist den zuständigen Stellen auf Verlangen vorzuzeigen.

7. Verlust des Passes ist den ausstellenden Behörden unverzüglich anzuzeigen.

8. Bei der Rückreise muß der Grenzübertritt innerhalb der im Grenzpa $B$ für jede Reise festgesetzten Frist erfolgen. Diese Frist kann in Dänemark nicht verlängert werden.

9. Möglichst bald nach der Ankunft am Bestimmurigsort in Dänemark oder spătestens 24 Stunden nach derselben múB ${ }^{*}$ derjenige, der einen fremden Staatsbürger beherbergt, der örtlichen Polizeibehörde dessen Ankunft anmelden. Die notwendigen Anmeldevordrucke sind bei den Ortspolizeibehörden erhaltlich. Die Abreise muß ebenfalls binnen 24 Stunden der Polizel mitgeteilt werden. Solche An- und Abmeldungen sind uberall dort vorzunehmen, wo der PaBinhaber während des Aufenthaltes in Dänemark übernachtet.
1

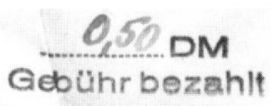

\section{F 017862}

\begin{tabular}{l|l} 
Familienname \\
Efternavn
\end{tabular}


Thygesen talte her på menigmands vegne. I Flensborg by udtalte SSF-sendemændene $\mathrm{i}$ november samme år, at det ikke var rimeligt at fastholde en slags Kongeågrænse. Gebyrerne for rejser nord for Kongeåen var en hindring, som var beklagelig, da »den kulturelle udveksling og den vekselvirkning, der altid finder sted over en grænse, bør være så fri som mulig. «" Klagerne førte til at den danske justitsminister rejste til Sydslesvig for at sætte sig ind i synspunkterne, med det resultat, at en betydelig lettelse $i$ adgang til at opnå visum til gentagne rejser blev indført fra 1951.

Næsten samtidig overgik pashøjheden fra 1. februar 1951 fra de allierede magter til Tyskland. Forhandlinger om denne omlægning havde været $\mathrm{i}$ gang længe, mødt med skepsis på dansk side. I danskbritisk paskontor i Flensborg var man ikke begejstret ved tanken om et muligt kommende samarbejde med tyskerne. Da der fra december 1948 var optræk til at den britiske del af paskontoret i Flensborg skulle gå over til tyskerne, advarede politimesteren i Aabenraa, som var ansvarlig for den danske afdeling af kontoret: Paskontoret havde til opgave at føre minutiøs kontrol med ansøgerne og fik derfor mange personlige oplysninger. Disse var hidtil holdt absolut lukkede for tyske øjne, »idet man selvsagt under ingen omstændigheder vil risikere, at uvedkommende tyske instanser måtte få kundskab om f.eks. ansøgeres nationalpolitiske indstilling og andre oplysninger af fortrolig art«. Hvis tysk personale skulle blive tilforordnet, ville politimesteren derfor øjeblikkelig lade alle dokumenter af enhver art bringe nord for grænsen. "Det må anses for utænkeligt at danske myndigheder vil lobe nogen risiko for, at dansk politi's personaloplysninger af grænsepolitisk art kan komme til tyske myndigheders kundskab med betydelig fare for indgreb og forfølgelser mod de pågældende fra tysk side, " hed det advarende fra Aabenraa. ${ }^{48}$

\section{På vej mod den åbne grænse}

Suveræniteten var imidlertid på vej til Tyskland. I 1951 oprettedes tyske generalkonsulater $i$ udlandet til varetagelse af pasudstedelse, og i Tyskland blev normale rejsepas herefter udstedt af tyske pasmyndigheder. "Allied military permit office $\mathrm{i}$ København, som nu i 6 år havde stået for udstedelsen af visum til Tyskland, lukkede. Det samme gialdt det allierede paskontor i Kiel (Permit Application Office). I Flensborg overtog det tyske landrådskontor på tysk side udstedelsen 


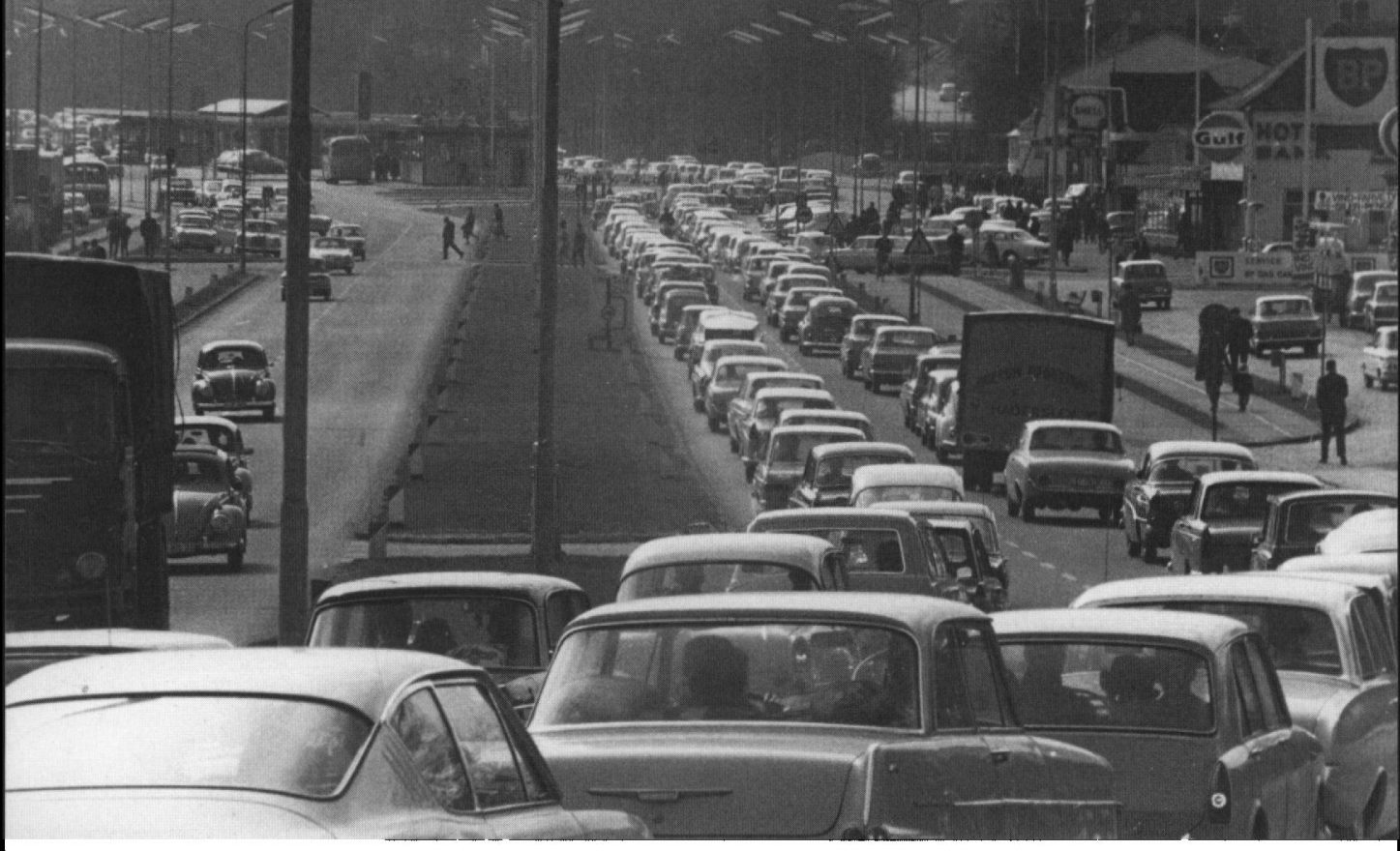

Fra begyndelsen af 1950'erne kom der for alvor gang i grænsetrafikken. Men der skulle stemples pas, og det gav på de store rejsedage ventetid. Lange bilkaer blev et tilbagevendende fænomen på f.eks. Skærtorsdage og Store Bededage. Det lettede forst

af de særlige grænsepas. ${ }^{49}$ Det fælles britisk-danske paskontor fortsatte en tid endnu af særligt hensyn til mindretallet, nu på rent danske hænder.

Alt $i$ alt var en ny periode indledt $i$ foråret 1951 . De nye visumregler betød, at antallet af rejser sydfra til Danmark, ikke mindst fra Sydslesvig, tog et mægtigt opsving. Der var åbnet for ikke kun foreningsrejser og rejser af social eller kulturel karakter. Også enkeltpersoner kunne rejse mere frit. Alene i sommeren 1951 besøgte omkring 11.000 voksne danske sydslesvigere Danmark på fællesrejse, 13.000 skolebørn var på sommerferieophold, og også enkeltvis kunne der rejses. I alt 30.000 dansksindede sydslesvigere skønnedes at have besøgt Danmark i sommeren 1951. Den lukkede grænse fandtes ikke længere. Sydslesvig lærte Danmark at kende, og Danmark lærte Sydslesvig at kende. ${ }^{50}$ Turistrejser var det nye fænomen, begunstiget af den stigende velstand også syd for grænsen og forbedrede muligheder for at købe fremmed valuta.

Nu stod kun få hindringer tilbage. Fra dansk-sydslesvigsk side så man hen til den dag, hvor hele visumordningen kunne ophæves - for den havde bevirket en sand papirkrig, stigende $i$ takt med antallet af rejser. "De der kender de enkelte sagers besværlige gang, vil kunne 
blev åbningstiden ved Padborgovergangen forlænget fra kl. 22.00 til 24.00 - til gavn for slægts- og venskabsforbindelser og for at muliggøre deltagelse $\mathrm{i}$ teater- og mødeliv hen over grænsen. Også åbning af fem helt små overgangssteder for den lokale befolkning ifølge en særlig anmærkning i deres pas blev gennemført, nemlig overgangene ved Frøslev/Ellund, Sofiedal/Jarlund, St. Jyndevad/Vesby, BejerskroGrøngård/Vestre og Højer/Rodenæs i 1957. ${ }^{52}$

Skridt for skridt gik liberaliseringen fremad. Fra 1. juli 1953 bortfaldt visumtvangen til Tyskland. Fra 1. august s.å. blev politimesteren i Aabenraa bemyndiget til uden videre at udstede visum til personer bosat i Sydslesvig. Endelig 1. juni 1954 kom fritagelsen for visum for tyske statsborgere for rejser til Danmark, Norge og Sverige. Et gyldigt rejsepas var herefter nok til at kunne passere grænsen.

Dermed var tiden løbet ud for det særlige grænsepas, som næsten siden grænsedragningen i 1920 i forskellige former og med afbrydelser havde lettet grænsepassagen i selve grænselandet. Endnu i 1955 udstedtes i alt ca. 7.500 af disse pas, syd for grænsen havde 25.000 pas gyldighed, alene i Flensborg 15.000. Passet blev ophævet fra 15. maj 1957 - herefter skulle alle skaffe sig et almindeligt rejse- eller nationalitetspas. Sidste rest af en pasmæssig særordning for grænselandet var borte.

Langt om længe var forholdene ved grænsen blevet »normaliseret«. Turiststrømmen hen over grænsen kunne for alvor begynde. En ny toldbygning $\mathrm{i}$ Kruså blev sat $\mathrm{i}$ arbejde, og blev indviet $1956 .{ }^{53}$

Alle senere ændringer var af praktisk art og tjente til at få trafikken til at glide problemfrit. I 1954 afskaffedes de såkaldte tællekort, som hidtil var blevet udfyldt $i$ den tyske paskontrol, med forsinkelser til følge. Et stempel i passet var herefter nok: Men også det blev snart et problem, i takt med trafikkens vækst. Al denne stempling forsinkede trafikken, og den virkede i stigende grad antikveret. »De brave danske betjente, der sidder i deres bure eller står udenfor ved den dansktyske grænse og stempler pas. Bang, bang, bang - dag ud, og dag ind; og om natten med ... Hvor længe vil den danske stat tolerere en sådan misbrug af menneskelig arbejdskraft," skrev Flensborg Avis den 19. juli 1962. Fra 1963 kunne tyskere nøjes med et Personalausweis. Passet var ikke længere en betingelse for grænsepassage. I juni 1966 blev der opsat paskontrolbokse, så bilister ikke behøvede at stige ud af vognen for at få passet kontrolleret - det blev herefter efterset fra de små bokse ved vejen. Samtidig blev toldeftersynet indskrænket 
til stikprøver. Det gav væsentlig nedsat ekspeditionstid, fra tre minutter til 20 sekunder blev det vurderet.

Sådan blev det ene lille skridt efter det andet taget for at lette grænsepassagen.

Det sidste skridt kom den 25. marts anno 2001. Fra den dag var det end ikke nødvendigt at vise passet ved grænsen. Schengen-aftalen var trådt $\mathrm{i}$ kraft. Der kunne køres frit over grænsen. En frihed og et samkvem og en kontakt blev virkeliggjort på en måde, så det for alvor kunne mærkes. Selv de hedeste ønsker i de to mindretal og i resten af befolkningen fra den lukkede grænses år syntes opfyldt.

Det åbnede muligheder - fremtiden vil vise, hvordan de bliver udnyttet.

FORKORTELSER

ADCB Arkivet ved Dansk Centralbibliotek for Sydslesvig

LAAab Landsarkivet for Sønderjylland, Aabenraa

Fl.A. Flensborg Avis

NOTER

1. Chr. Johannsens dagbog 1. aug. 1920, ADCB P 144.

2. Henrik Becker-Christensen: Den nye grænse, i: Grænsen i 75 år, 1995, s. 42f.

3. Anna Holmgaards dagbog, ADCB P 459.

4. Lis Jacobsen: Det lukkede Land. Sydslesvig Frit. Aug. 1946. Tryksag i ADCB P 312-3.

5. Eksempel på grænsepas 1921 i Sønnich Volquardsens arkiv, ADCB P 554.

6. Journalsag nr. 87 »Udflugtskort«, Politiadjudanten, LA Aab.

7. Eksempel på 10-øres pas i Heinrich Linaus arkiv, ADCB P 508.

8. Overenskomstens tekst findes i LA Aab Politiadjudanten jr. 87.

9. Journalsag nr. 87 "Udflugtskort", Politiadjudanten, LA Aab.

10. Som note 7 .

11. Beretninger fra konsulatet i Flensborg 6. og 20. juni 1940, Politiadjudanten jr. 6262, LA Aab. Se også Henrik Skov
Kristensen: Grænsen og besættelsen, i: Grænsen i 75 år, 1995, s. 79-109.

12. Redegørelse af politimester Brix, Tønder 15. juli 1945, ADCB I 61, 65.26-1 (=LA Aab Politikommandøren pk. 221). Lars N. Henningsen: Kulturelles Leben der dänischen Minderheit, i: Flensburger Beiträge zur Zeitgeschichte 4, Flensburg 1999, s. 263-265.

13. Anna Rud Bentholm: Ved Grænsen, SJy Årb 1986 s. 199-205. Chr. Stenz: Dansk Lærer i grænselandet, 1982, s. 146. Aage Emil Hansen: Told- og grænsekontrol i efterkrigstiden, i: Grænsen i 75 ăr, 1995, s. 129-133.

14. Svend Johannsens dagbog 8. og 11 . maj 1945, ADCB P 201-10.

15. Svend Johannsens dagbog 14., 15., 17., 29. maj, 2., 4., 13., 26. juni 1945. ADCB P 201-10.

16. Svend Johannsens dagbog 4. juli og 9 . sept. 1945. ADCB P 201-10.

17. Hans Peter Johannsen: Sieben schleswigsche Jahrzehnte, 1978 s. 75.

18. Se f.eks. Deutscher Volkskalender Nordschleswig 1949 s. 86, 1950 s. 93, 101, 106. Schriften der Heimatkundlichen Arbeitsgemeinschaft für Nordschleswig Heft 75, 2000 s. 149, 185. LA Aab Politikommandøren. Rapport: "Det tyske Mindretal i Nordslesvig 1945-55«. 
19. Se f.eks. Frants Thygesens rapporter om forholdene i Sydslesvig sept.-okt. 1945, ADCB P 312-3.

20. Knud Kretzschmer (red.): Sydslesvigsk Dagbog I, 1947, nr. 39, 46, 60, 76, 78 110, 114, 186.

21. Retningslinjer vedr. "Frontalier Travel« 3/4 1946, ADCB I 65.26-1.

22. "Stillingen i Sydslesvig, juli og august 1946«, Frants Thygesens arkiv, ADCB P 312-3.

23. Dette var næppe lovligt. Passene gjaldt kun rejser til Kongeåen. Alligevel blev de benyttet til rejser over hele Danmark. I 1947 krævede briterne reglerne overholdt, men Dansk Generalsekretariat protesterede ihærdigt. Se SSF til British-Danish-Passport-Office 28/2 1947, ADCB I 61, 65.26-1.

24. Sydslesvigsk Dagbog I nr. 186. - Cirkulære vedr. dansk-britisk paskontor 4/9 1945: ADCB I 61.25-1.

25. Headquarter Kiel til DGS 27/2 1948, ADCB I 61, 65.26-1.

26. Fl.A. 11/3-1948, avisudklip i ADCB I 61.02.13-2. Avisudklip 11.-15. maj 1948 i LAAab Aabenraa politi 1516.

27. Thygesen til justititsministeren $1 / 8$ 1950, ADCB I 61, 65.26.1.

28. Peter R. Petersen, Flensborg til Thygesen 25/4 1947, ADCB I 61, 65.26-1.

29. Sonderjyden $23 / 12$ 1947, udklip i LAAab Aabenraa politi 1516.

30. Flensborg Avis $19 / 7-49$, i LA Aab Aab politi 1516.

31. Hans Asmussen 9/2 1950, ADCB I 4544.

32. Avisudklip maj-juni 1948 i LA Aab Aabenraa politi 1516.

33. Meta Rös arkiv, ADCB P 214.

34. Jørgen Pors' dagbog 14/12 1946, ADCB P 197.

35. Fl.A. 6/4-1947 og 12/11-1948, avisudklip i ADCB I 61, 65.26.3.

36. Breve og akter 4. aug.-dec. 1945 i Thygesens arkiv, ADCB P 312-3.
37. Martin Mortensens dagbøger, ADCB P 103.

38. Jørgen Pors' dagbøger 17. og 21/12 1946, ADCB P 197.

39. Torben Glahns dagbøger 2-27/9 1946, ADCB P 316.

40. Birthe Andrups dagbog 14/8 1946, ADCB P 439.

41. Birthe Andrup til moderen 6. oktober 1946, ADCB P 439.

42. Helga Pedersen: "Grænsetrafikken mellem Nord- og Sydslesvig ", i: Venstres Maanedsblad nr. 10. dec. 1951, eksemplar i ADCB I 61, 65.26-2. Jvfr. citat af Helga Pedersen i Fl. A. 12/11952.

43. Justitsminister Helga Pedersen, cit. i Fl. Avis 12.1.1952.

44. Årsberetning cit. i Flensborg Avis 4/1 1950, avisudklip i LA Aab, Aabenraa politi 1516.

45. Redegørelse 12/1 1951 i ADCB I 61, 65.26-2.

46. Thygesen $1 / 81950$ til justitsministeren, ADCB I 61, 65.26.1.

47. SSF Flensborg by til Justitsministeriet 16/11 1950, ADCB I 61, 65.26.1.

48. Politimesteren i Aabenraa 14/12 1948, LAAab Politikommandøren 221 XIV Grænsepassage.

49. Avisudklip $23 / 9-1950,7 / 1$ og $12 / 1$ 1951 i LAAab Aabenraa politi 1516. Kgl. Dansk Konsulat 3/7-1951i ADCB I 61. 65.26-2.

50. Dansk Generalsekretariat til Flensborg Avis 16/11 1951, ADCB I 61.65.26-2.

51. Thygesen til Kgl. Dansk Konsulat 23/ 7 1951, ADCB I 61, 65.26-2.

52. Aage Emil Hansen: Told- og grænsekontrol i efterkrigstiden, i: Grænsen i 75 år, 1995, s. 138f. Avisudklip i ADCB I 61. 65.26.2. og 4.

53. Aage Emil Hansen: Told- og grænsekontrol i efterkrigstiden, i: Grænsen i 75 år, 1995, s. 136-141. 